Vol. 3, No 1, Juni 2020

Hal 40-53

\title{
ANALISIS TINGKAT KERUSAKAN DAN VALUASI EKONOMI HUTAN MANGROVE DI PERAIRAN PANTAI DESA NISOMBALIA KECAMATAN MARUSU KABUPATEN MAROS
}

\section{(Damage Level Analysis and Economic Valuation of Mangrove Forest in The Coastal Waters Nisombalia Village Marusu District Maros Regency)}

\author{
Haryanto 1), Asbar ${ }^{2)}$ dan Hamsiah 2) \\ ${ }^{1}$ Mahasiswa Pascasarjana Universitas Muslim Indonesia \\ ${ }^{2}$ Dosen Program Studi Manajemen Pesisir dan Teknologi Kelautan, \\ Pascasarjana Universitas Muslim Indonesia \\ Korespondensi:Haryantoasri22@gmail.com
}

Diterima: tanggal 20 Januari 2020; Disetujui 1 Maret 2020

\begin{abstract}
This study aimed to analyze the potential of mangrove resources in the study area, analyze the damage to mangrove forests in the study area, and formulate management strategies in the research area that repair mangrove damage. The method used in this study is the analysis of the level of damage based on a direct survey of mangrove conditions, interpretation of Landsat 8 imagery for changes in mangrove cover area, interviews and questionnaires for mangrove economic valuations and SWOT analysis for strategic direction directives. results obtained from mangrove conditions for Rhizopora apiculata showed the highest percentage of closure was $57.81 \%$. The results of image interpretation also showed a reduction and additional area from 2015 to 2019 and for the total economic value in the village of Nisombalia at the time of the study amounted to 35,442,557,718 Million Rupiah. There are 2 directions of mangrove ecosystem rehabilitation strategies which are the main priorities in Nisombalia Village, namely: 1) Restoring mangrove functions in accordance with the ecological rehabilitation space pattern, 2) procurement of mangrove cultivation facilities (nurseries and seedlings) which are managed directly by the community.
\end{abstract}

Keywords: Mangrove Damage, Economic Value, Rehabilitation, SWOT

\begin{abstract}
ABSTRAK
Penelitian ini bertujuan untuk menganalisis potensi sumberdaya mangrove pada wilayah penelitian, menganalisa kerusakan hutan mangrove pada wilayah penelitian, dan merumuskan strategi pengelolaan pada wilayah penelitian yang mengalami kerusakan mangrove. Metode yang digunakan dalam penelitian ini yaitu analisis tingkat kerusakan berdasarkan survey langsung kondisi mangrove, interpretasi citra Landsat 8 untuk perubahan luasan penutupan mangrove, wawancara dan pengisian kuisioner untuk valuasi ekonomi mangrove dan analisis SWOT untuk penentuan arahan strategi. Hasil yang di dapatkan kondisi mangrove untuk jenis Rhizopora apiculata menunjukkan persentase penutupan tertinggi sebesar $57,81 \%$. Hasil interpretasi citra juga menunjukkan adanya pengurangan dan penambahan luasan dari tahun 2015-2019 dan untuk total nilai ekonomi di Desa Nisombalia pada saat penelitian adalah sebesar Rp 35.442.557.718. Ada 2 arahan strategi rehabilitasi ekosistem mangrove yang menjadi prioritas utama di Desa Nisombalia yaitu: 1) Mengembalikan fungsi mangrove sesuai dengan pola ruang ekologi rehabilitasi; 2) pengadaan sarana budidaya mangrove (pembibitan dan penyemaian) yang dikelola langsung oleh masyarakat
\end{abstract}

Kata kunci: Kerusakan Mangrove, Nilai Ekonomi, Rehabilitasi, SWOT 



\section{PENDAHULUAN}

Indonesia merupakan salah satu negara kepulauan terbesar di Asia teggara yang mempunyai potensi sumberdaya alam pesisir yang luar biasa dengan keanekaragaman ekosistem didalamnya. Salah satu ekosistem di wilayah pesisir Indonesia adalah ekosistem mangrove.

Mengingat semakin rusaknya kondisi mangrove, maka data dan informasi mengenai kondisi mangrove di berbagai kawasan di Indonesia perlu dikaji untuk keperluan pengelolaan mangrove yang berkelanjutan, sehingga fungsi ekologisnya dapat tetap terjaga.

Penilaian ekonomi dari ekosistem hutan mangrove di Pesisir pantai desa Nisombalia perlu dilakukan sehingga dapat memberikan gambaran tentang nilai ekonomi ekosistem mangrove di Pesisir pantai desa Nisombalia tersebut, serta dapat dirumuskan strategi pengelolaan hutan mangrove yang berkelanjutan dengan tetap memperhatikan aspek fungsi dan peran mangrove.

Penelitian ini bertujuan untuk menganalisis potensi sumberdaya mangrove pada wilayah penelitian, menganalisa kerusakan hutan mangrove pada wilayah penelitian, dan merumuskan strategi pengelolaan pada wilayah penelitian yang mengalami kerusakan mangrove. Selain itu, diharapkan dapat memberikan informasi kepada masyarakat, pihak pemerintah, dan instansi - intansi terkait lainnya agar bisa digunakan untuk bahan pertimbangan dalam usaha rehabilitas mangrove.

\section{MATERI DAN METODE}

\section{Waktu dan Lokasi Penelitian}

Penelitian ini dilaksanakan pada tanggal 14 Agustus sampai tanggal 30 September 2019 di pesisir pantai Desa Nisombalia, Kecamatan Marusu Kabupaten Maros Provinsi Sulawesi Selatan. 


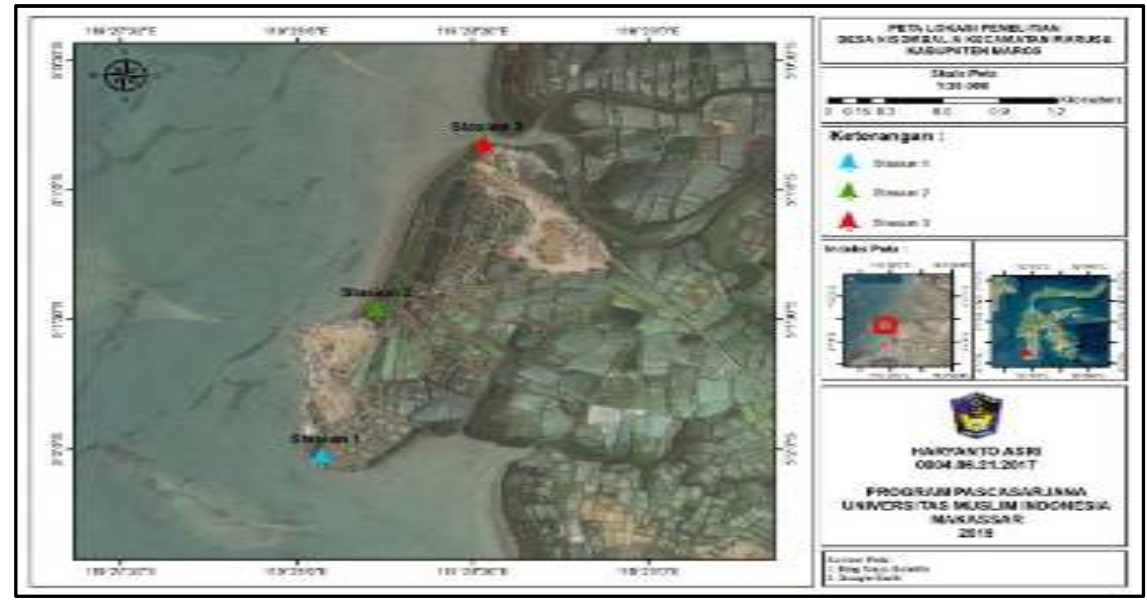

Gambar 1. Peta lokasi penelitian

\section{Alat dan Bahan}

Alat dan bahan yang digunakan dalam penelitian ini yaitu kamera untuk dokumentasi,GPS untuk mengetahui posisi pengamatan,meteran untuk beberapa pertimbangan tertentu oleh mengukur panjang transek, tali untuk peneliti berdasarkan ciri atau sifat-sifat membuat transek,alat tulis untuk populasi yang sudah diketahui mencatan, kuisioner untuk wawancara, sebelumnya (Notoatmodjo, 2002). personal computer untuk input data citra, software ArcGIS, ER-Mapper untuk mengolah data citra, peta rupa bumi dan citra Landsat 8 tahun 20132018 .

\section{Teknik Pengumpulan Data}

Berdasarkan tujuan penelitian yang ingin dicapai maka, penelitian ini merupakan penelitian deskriptif. Teknik pengumpulan data deskriptif dapat dilakukan dengan observasi lapangan, survei dan pemetaan, 20\% dan peta rupa bumi. wawancara, kuesioner dan studi pustaka (Setiyowati, 2016).

\section{Teknik Penentuan Responden}

Penentuan responden pada masyarakat lokal dilakukan dengan teknik purpossive sampling artinya penentuan lokasi dan responden dengan Analisis Data

\section{Analisis Perubahan Luasan Mangrove}

Penentuan perubahan luasan penutupan mangrove di Desa Nisombalia yaitu dengan menggunakan data citra dengan waktu yang berbeda. Data citra yang digunakan yaitu citra satelit Landsat 8 tahun 2015 sampai tahun 2019 dalam format digital, dengan penutupan awan kurang dari

2. Analisis Potensi Sumberdaya Mangrove

\section{a. Analisis Potensi Ekonomi}


1. Nilai Ekonomi Total merupakan Komposis jenis dan struktur vegatasi penjumlahan dari keseluruhan nilai dilakukan dengan menganalisa penggunaan dan nilai tanpa parameter yang mengacu pada penggunaan tergantung pada Natividad et.al. (2015), yaitu: kerapatan sepesifik kegunaan/preferensi jenis, kerapatan relative jenis, frekuensi orang dan tempat.

jenis, frekuensi relative jenis,

2. Nilai Manfaat Langsung penutupan jenis, penutupan relative merupakan Perhitungan nilai jenis, dan indeks nilai penting. manfaat langsung dengan c. Analisis Tingkat Kerusakan menggunakan pendekatan harga Kategori baik atau rusaknya pasar (Market Price), dimana biaya ekosistem hutan mangrove pada suatu produksi dan transportasi harus daerah merujuk pada "Keputusan dikurangkan untuk mendapatkan Menteri Negara Lingkungan Hidup nilai total dari hasil produk tersebut Nomor : 201 Tahun 2004 Tentang “

3. Nilai manfaat tidak langsung Kriteria Baku dan Pedoman Penentuan adalah fungsi hutan mangrove Kerusakan Mangrove”. sebagai penyuplai unsur hara, d. Arahan Strategi Pengelolaan penyerap karbondioksida (CO2), Berdasarkan hasil analisa tempat wisata dan kemampuan sebelumnya selanjutnya dilakukan untuk menahan ombak sehingga analisis SWOT (Strength, Weaknes, tidak terjadi abrasi Opportuniy and Theart). Analisis

4. Nilai manfaat pilihan adalah nilai SWOT digunakan untuk merumuskan potensila yang dapat dimanfaatkan strategi rehabilitasi mangrove, bersifat untuk masa yang akan datang dari kualitatif dengan melakukan hutan mangrove identifikasi secara sistematis terhadap

5. Nilai mafaat keberadaan adalah berbagai faktor yang melingkupinya. nilai kepedulian seseorang akan Analisis didasarkan pada logika keberadaan suatu sumberdaya alam yang dapat memaksimalkan kekuatan atau makhluk hidup lainnya (strength) dan peluang (opportunities), b. Analisis Potensi Ekologis namun secara bersamaan dapat Identifikasi jenis Mangrove meminimalkan kelemahan (weakness) mengacu pada Noor et.al. (2006). dan ancaman (threats).Dengan 
demikian perencana strategis harus lokasi penelitian sehingga parameter ini menganalisis faktor-faktor strategis dimasukkan dalam kategori sangat yang ada (kekuatan, kelemahan, sesuai. Adapun spesies mangrove peluang dan ancaman) dalam kondisi tersebut antara lain : Achanthus yang ada pada saat ini. Adapun Ilicifolius, Excoearia agallocha, langkah-langkah yang dilakukan dalam Avicennia marina, Avicennia alba, analisis SWOT (Strength, Weaknes, Ceriops tagal, Lumnitzera racemosa, Opportuniy and Theart) adalah sebagai Rhizophora apiculata, Rhizophora berikut: (1) Identifikasi Kekuatan, stylosa, dan Sonneratia alba. Akan Kelemahan, Peluang dan Ancaman; (2) tetapi, ada 8 jenis mangrove yang Analisis SWOT; (3) Arahan Strategi masuk kedalam stasiun yang dibuat Pengelolaan Hasil Analisa SWOT. pada saat penelitian yang dilakukan. Diantaranya yaitu, Rhizopora apiculate,

\section{HASIL DAN PEMBAHASAN}

\section{Gambaran Umum Lokasi Penelitian}

Desa Nisombalia Merupakan salah satu Desa yang ada diwilayah pemerintahan kecamatan Marusu Kabupaten Maros Provinsi Sulawesi Selatan yang posisi geografisnya berada diantara $4^{\circ} 59^{\prime} 14.9^{\prime \prime}-5^{\circ} 02^{\prime} 39.0^{\prime \prime}$ LS dan $119^{\circ} 28^{\prime} 54.3^{\prime \prime}$ - 119³0'43.7" BT

Secara administrative Desa Nisombalia termasuk dalam kecamatan Marusu yang terbagi dalam 4 dusun yaitu: Dusun Mambue, Dusun TalaTala, Dusun Kuri Lompo, dan Dusun Kuri Caddi

\section{Kondisi Ekologi Mangrove}

Berdasarkan hasil pengamatan di lapangan, ditemukan 10 spesies mangrove yang tumbuh di sekitar
Rhizopora stylosa, Avecennia marina, Avecennia alba, Sonneratia alba, Ceriops tagal, dan Excoearia agallocha.

Untuk mangrove jenis Avicennia marina, Avicennia alba, Rhizophora apiculata, Rhizophora stylosa, dan Sonneratia alba banyak ditemukan di sebelah selatan dari lokasi penelitian yang merupakan daerah green belt yang berbatasan langsung dengan lautan. Untuk jenis Achanthus ilicifolius dan Lumnitzera racemose banyak ditemukan di sekitar pinggiran pematang tambak.

Parameter ini dimasukkan dalam kategori sangat sesuai karena didukung oleh pernyataan Dahuri (2003) bahwa, Ekosistem mangrove di Indonesia 
memiliki tingkat keanekaragaman jenis (Sonneratia), yang tertinggi di dunia. Vegetasi hutan (Avicennia) mangrove di Indonesia tercatat sebanyak 202 jenis yang terdiri atas 89 jenis pohon, 5 jenis palem, 19 jenis liana, 44 jenis epifit dan 1 jenis sikas. Namun demikian hanya terdapat kurang lebih 47 jenis tumbuhan yang spesifik hutan mangrove dan umumnya pada vegetasi ini terdapat salah satu jenis tumbuhan sejati atau dominan yang termasuk dalam empat famili yaitu Rhizophoraceae (Rhizophora, Bruguiera dan Ceriops), Sonneratiaceae Tabel 1.Sebaran jenis mangrove

\begin{tabular}{clccc}
\hline No. & \multicolumn{1}{c}{ Jenis } & Stasiun 1 & Stasiun 2 & Stasiun 3 \\
\hline 1. & Rhizophora apiculata & $*$ & $*$ & $*$ \\
\hline 2. & Rhizophora stylosa & $*$ & $*$ & $*$ \\
\hline 3. & Avicennia marina & - & $*$ & - \\
\hline 4. & Avicennia alba & - & $*$ & $*$ \\
\hline 5. & Sonneratia alba & $*$ & - & - \\
\hline 6. & Ceriops tagal & - & $*$ & - \\
\hline 8. & Excoearia agallocha & - & - & $*$ \\
\hline
\end{tabular}
Sumber: Hasil Penelitian 2019

\section{Indeks Nilai Penting}

Indeks nilai penting (INP) menyatakan kepentingan suatu jenis suatu komunitas mangrove (Bengen, tumbuhan dan juga menggambarkan 2004). Indeks nilai penting mangrove tingkat penguasaan jenis dalam suatu dapat dilihat pada table berikut ini: komunitas. Selain itu, INP juga Tabel 2. Indeks Nilai Penting

\begin{tabular}{ccccccc}
\hline Stasi & Jenis & Rdi & Rfi & RCi & \multirow{2}{*}{ INP } & \multirow{2}{*}{ Keterangan } \\
\cline { 3 - 5 } un & Mangrove & $(\%)$ & $(\%)$ & $(\%)$ & & \\
\hline I & S. alba & 13,52 & 33,44 & 22,36 & 69,32 & Kurang Penting \\
\hline & R. stylosa & 21,62 & 22,07 & 18,90 & 62,59 & Tidak Penting \\
\hline
\end{tabular}

Avicenniaceae dan Meliaceae (Xylocarpus). Semakin banyak vegetasi mangrove yang tumbuh di sekitar lokasi rehabilitasi maka semakin mudah mangrove tersebut untuk mempertahankan ekosistemnya.

Penyebaran jenis mangrove pada lokasi penelitian tidak merata. Pada stasiun I ditemukan 3 jenis mangrove, pada stasiun II ditemukan 5 jenis mangrove, dan pada stasiun III ditemukan 4 jenis mangrove. 


\begin{tabular}{|c|c|c|c|c|c|c|}
\hline & R. apiculata & 62,54 & 33,44 & 56,64 & 152,62 & Penting \\
\hline & A. marina & 2,70 & 11,04 & 2,10 & 15,84 & Tidak Penting \\
\hline & Jumlah & 100 & 100 & 100 & 300 & \\
\hline \multirow[t]{5}{*}{ II } & C. tagal & 11,12 & 14,22 & 18,76 & 44,10 & Tidak Penting \\
\hline & A. marina & 52,77 & 43,10 & 50,14 & 146,01 & Kurang Penting \\
\hline & A. alba & 19,44 & 28,45 & 16,74 & 64,63 & Tidak Penting \\
\hline & R. stylosa & 16,67 & 14,22 & 14,36 & 45,25 & Tidak Penting \\
\hline & Jumlah & 100 & 100 & 100 & 300 & \\
\hline \multirow[t]{4}{*}{ III } & $\begin{array}{l}\text { Excoearia } \\
\text { agallocha }\end{array}$ & 22,23 & 40,00 & 40,98 & 103,21 & Kurang Penting \\
\hline & A. alba & 44,44 & 40,00 & 22,84 & 107,28 & Kurang Penting \\
\hline & R. apiculata & 33,33 & 20,00 & 36,18 & 89,51 & Kurang Penting \\
\hline & Jumlah & 100 & 100 & 100 & 300 & \\
\hline
\end{tabular}

Sumber: Hasil Penelitian 2019

Analisis data yang didapatkan jenis lainnya. Rendahnya ketahanan bahwa jenis mangrove yang memiliki terhadap gejala alam serta besarnya nilai penting tertinggi yaitu jenis eksploitasi mengakibatkan jenis-jenis Rhyzophora apiculata yaitu $152,62 \%$ tersebut berkurang dari tahun ke tahun sedangkan jenis Avicennia marina (Widhi, 2009).

memiliki nilai terendah yaitu $15,84 \%$. Perubahan Luasan Penutupan

Hal ini menjadi acuan bahwa Mangrove

jenis Rhizopora apiculata mampu Perubahan luasan penutupan direkomendasikan apabila akan mangrove diamati dengan diadakan penanaman, karena jenis menggunakan teknologi penginderaan tersebut dominan tumbuh di sepanjang jauh. Sistem penginderaan jarak jauh pesisir Desa Nisombalia. Keaadan ini secara umum terdiri dari objek dapat dilihat dalam indeks nilai penting permukaan bumi yang diindera atau yang dimiliki oleh suatu jenis diamati menggunakan sensor pengamat mangrove. INP yang tinggi yang diletakkan pada wahana satelit menggambarkan bahwa jenis-jenis ini atau kapal yang bergerak pada orbitnya mampu bersaing dengan lingkungannya dengan pengamatan yang berulang dan dan disebut jenis dominan. Sebaliknya, liputan yang luas (Thomas dan Ralph, rendahnya INP pada jenis tertentu 2000).

mengindikasikan bahwa jenis ini Klasifikasi citra yang dilakukan kurang mampu bersaing dengan pada penelitian ini adalah metode lingkungan yang ada disekitarnya serta kemiripan maksimum (maximum 
likelihood). Asumsi dari algoritma ini interpretasi citra satelit Landsat 8 tahun adalah objek yang homogeny selalu 2015, luas penutupan di Desa menampilkan histogram yang Nisombalia adalah sebesar 122,23 Ha terdistribusi normal. Berdasarkan hasil disajikan pada gambar 12 berikut:

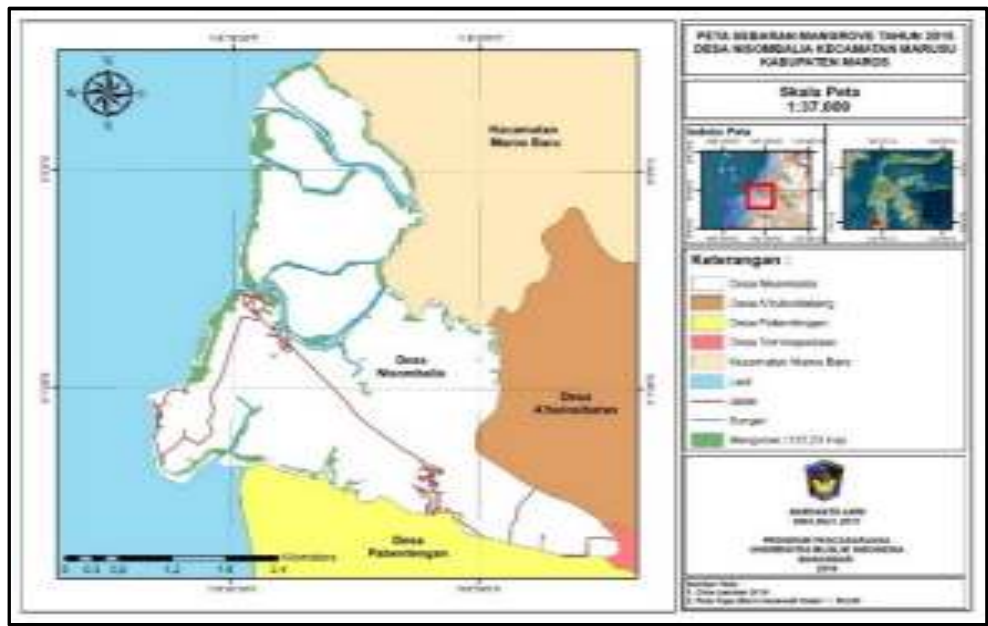

Gambar 2.Peta sebaran mangrove 2015

Dapat dilihat bahwa mangrove sungai. Pertumbuhan mangrove di tumbuh hampir di sepanjang pesisir kawasan pantai ini tampak tidak begitu Desa Nisombalia ini walaupun ada juga padat karena masih banyak lahan-lahan sebagian yang tumbuh di daerah hutan mangrove yang tampak kosong pinggiran tambak dan juga pinggiran dan tidak ditumbuhi mangrove.

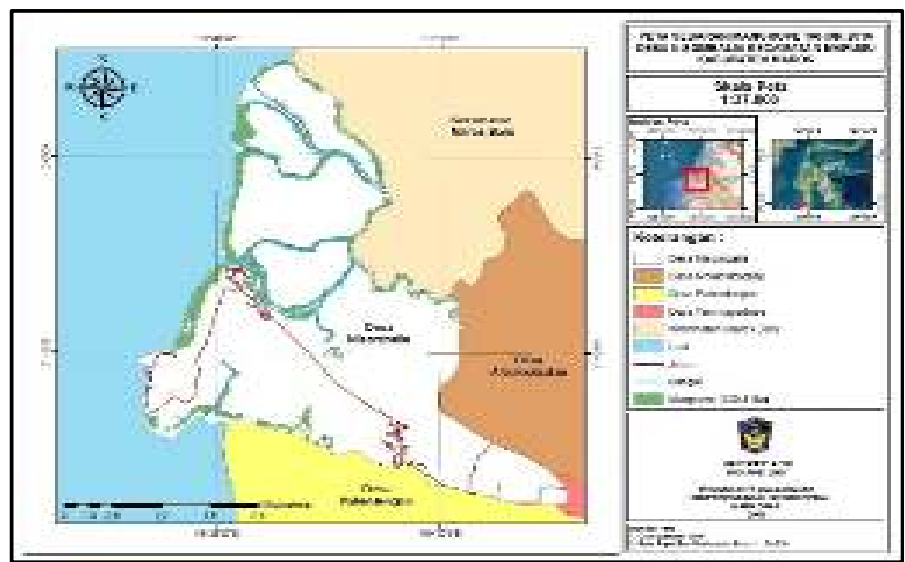

Gambar 3. Peta sebaran mangrove 2016

Tampak dari hasil interpretasi citra mangrove yang dilakukan oleh luasan mangrove bertambah dari tahun komunitas masyarakat maupun dari sebelumnya. Hal ini disebabkan karena instansi pemerintah. adanya kegiatan penanaman pohon 


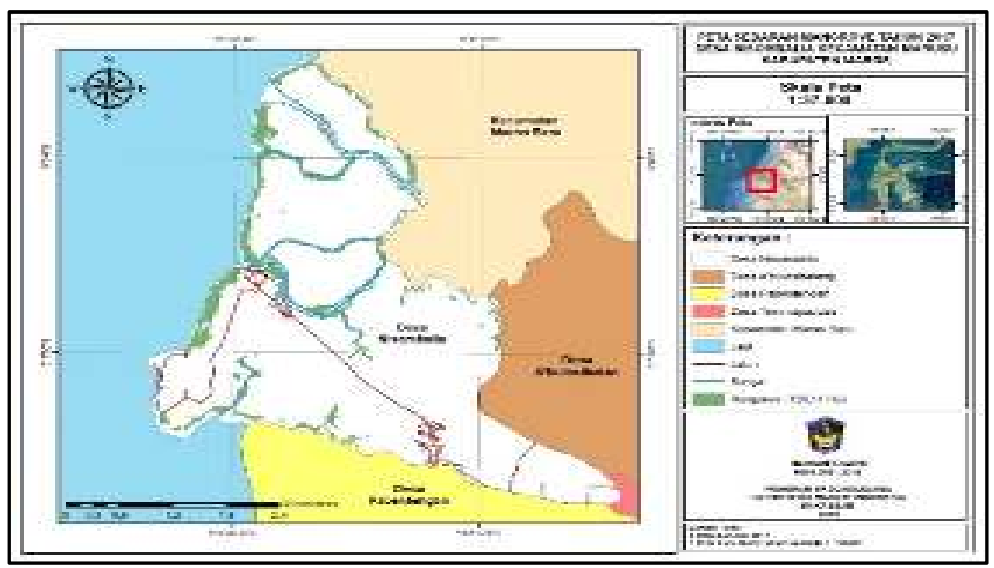

Gambar 4. Peta sebaran mangrove 2017

Tampak dari hasil interpretasi dengan pernyataan Ghufran (2012), citra luasan mangrove berkurang dari menyatakan bahwa yang menyebabkan tahun sebelumnya. Hal ini disebabkan rusaknya ekosistem mangrove salah karena masih adanya kegiatan konversi satunya yaitu pembukaan lahan menjadi lahan tambak. Hal ini sesuai menjadi tambak

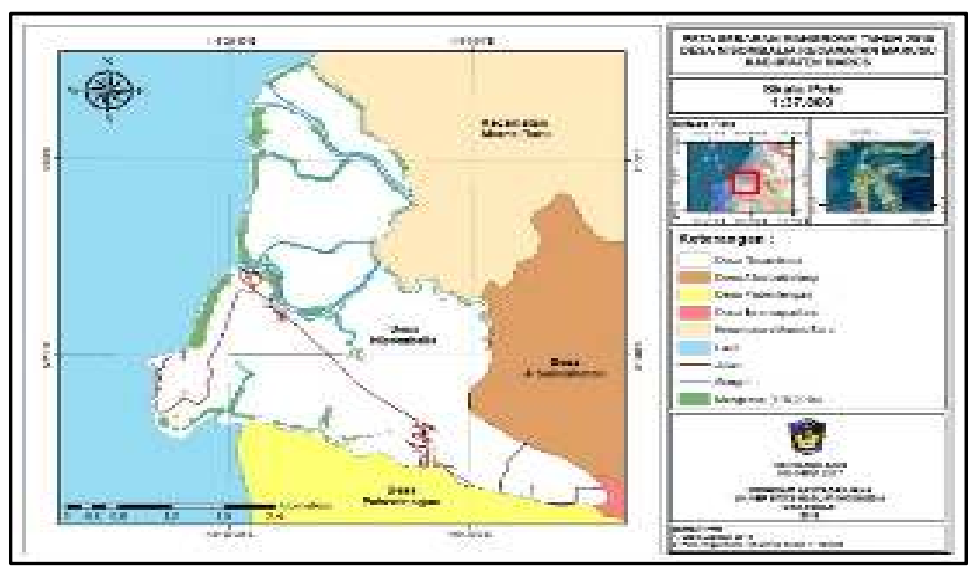

Gambar 5. Peta sebaran mangrove 2018

Hasil interpretasi citra terlihat meningkat. Tidak hanya itu, bahwa adanya penurunan luasan yang pembabatan habis ekosistem mangrove terjadi pada tahun 2018. Hal ini juga dilakukan oleh masyarakat diluar disebabkan karna konversi lahan desa Nisombalia. mangrove menjadi lahan tambak sangat 


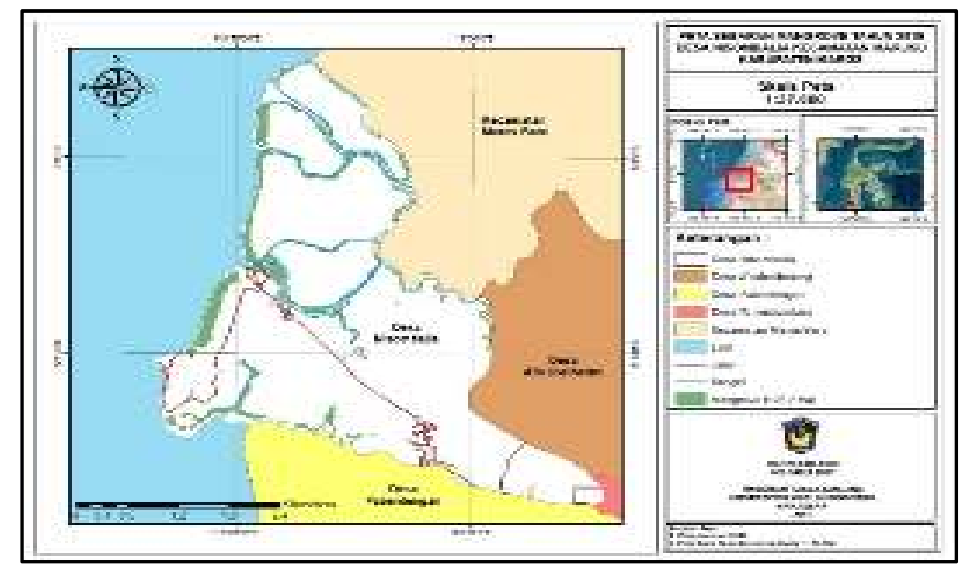

Gambar 6. Peta sebaran mangrove 2019

Berdasarkan hasil interpretasi Berikut perubahan luasan citra satelit Landsat 8 tahun 2019 mangrove di Desa Nisombalia yang terlihat peningkatan luasan hutan disajikan pada tabel berikut ini : mangrove dari tahun sebelumnya.

Tabel 3. Perubahan luasan mangrove di Desa Nisombalia

\begin{tabular}{ccc}
\hline No & Tahun & Luas $(\mathrm{Ha})$ \\
\hline 1 & 2015 & 122,23 \\
\hline 2 & 2016 & 123,30 \\
\hline 3 & 2017 & 120,11 \\
\hline 4 & 2018 & 118,30 \\
\hline 5 & 2019 & 125,20 \\
\hline
\end{tabular}

\section{Valuasi Ekonomi Mangrove}

Evaluasi ekonomi adalah suatu upaya untuk memberikan nilai kauntitif terhadap barang dan jasa yang manfaat langsung, manfaat tidak dihasilkan oleh sumber daya alam dan langsung,manfaat pilihan, dan manfaat lingkungan terlepas dari apakah nilai keberadaan seperti yang terlihat pada pasar tersedia atau tidak Fauzi, (2006). tabel 4 berikut ini :

Tabel 4. Nilai Ekonomi

\begin{tabular}{|c|c|c|c|}
\hline \multirow{2}{*}{ No } & \multirow{2}{*}{ Jenis Manfaat } & Total Nilai Ekonomi & \multirow{2}{*}{$\%$} \\
\hline & & (Rp/Tahun $)$ & \\
\hline \multirow[t]{4}{*}{1} & Nilai Manfaat Langsung & & \\
\hline & *Pontensi Kayu Bakar & 960.000 & 0,003 \\
\hline & *Penangkapan Ikan & 18.498 .000 & 0,052 \\
\hline & *Penangkapan Kepiting & 10.680 .000 & 0,030 \\
\hline
\end{tabular}

\section{Nilai Ekonomi Total}

Total nilai ekonomi di Desa Nisombalia adalah nilai ekonomi dari

$$
\text { (1) }
$$




\begin{tabular}{rlrr}
\hline & *Penangkapan Kerang & 4.560 .000 & 0,013 \\
\cline { 2 - 4 } & Jumlah & 34.698 .000 & 0,098 \\
\hline 2 & Nilai Manfaat Tidak & & \\
& Langsung & & \\
\hline & *Penahan Abrasi & 8.411 .471 .158 & 23,685 \\
\cline { 2 - 4 } & *Unsur Hara & 22.010 .160 & 0,062 \\
\cline { 2 - 4 } & *Penyerap Karbon & 255.382 .960 & 0,719 \\
\cline { 2 - 4 } & Jumlah & 8.688 .864 .278 & 24,466 \\
\hline 3 & Manfaat Pilihan & 26.292 .000 & 0,074 \\
\hline 4 & Manfaat Keberadaan & 35.513 .604 .278 & 75,362 \\
\hline & Nilai Ekonomi Total & & 100 \\
& (NET) & & \\
\hline
\end{tabular}

Dari table diatas menunjukkan pengelolaan ekosistem secara strategis. bahwa nilai manfaat keberadaan yang Arahan rehabilitasi ekosistem memiliki nilai terbesar yaitu $\mathrm{Rp}$ mangrove di susun berdasarkan atau 26.763.750.000 atau setara 75,362\% mempertimbangkan dimensi dari nilai ekonomi total. Kemudian pembangunan berkelanjutan (ekologi, diikuti nilai manfaat tidak langsung ekonomi, sosial, budaya dan sebesar $\mathrm{Rp}$ 8.688.864.278 atau setara kelembagaan). Input data mengenai dengan 24,466 \% dari nilai eknomi aspek ekologis merupakan hasil total. Selanjutnya nilai manfaat pengukuran dan analisis yang langsung langsung sebesar Rp 34.698.000 atau pada ekosistem mangrove selama setara dengan $0,098 \%$ dari nilai penelitian, input data social dan ekonomi total. Dan nilai manfaat ekonomi merupakan hasil wawancara pilihan sebesar $\mathrm{Rp} 26.292 .000$ atau dengan para responden yang telah setara dengan $0,074 \%$ dari nilai ditentukan sebelumnya dan input data ekonomi total.

\section{Arahan Strategi Pengelolaan} Wilayah Pesisir Pantai Kab. Pangkep dan Pinrang

Formulasi strategi rehabilitasi ekosistem hutan mangrove memerlukan suatu proses analisis secara multidimensi dengan mengakomodir semua aspek yang berkaitan dengan sekunder yang diperoleh dari berbagai instansi terkait.

Untuk mengarahkan strategi rehabilitasi ekosistem mangrove di kawasan tersebut berdasarkan input ekologis, social, budaya dan ekonomi, maka dilakukan analisis dengan menggunakan analisis SWOT 
(Strength, Weakness, Opportunity, dan Lembaga terhadap pengelolaan Threat).

Analisis SWOT merupakan ekosistem mangrove.

Unsur ancaman (threat) antara pemilihan hubungan atau interaksi lain: Pembukaan lahan tambak tanpa antar unsur-unsur internal yaitu adanya tindak lanjut perbaikan lahan, kekuatan dan kelemahan terhadap tingginya abrasi, Adanya pemanfaatan unsur-unsur eksternal yaitu peluang dan lahan dengan sistem kontrak, ancaman. Unsur kekuatan (strength) Penebangan liar dari masyarakat luar antara lain: Pemahaman masyarakat desa Nisombalia, Pelibatan masyarakat terhadap fungsi pelestarian mangrove harus lebih intensif

semakin membaik, adanya lembaga

Berdasarkan faktor internal dan untuk memonitoring perkembangan eksternal tersebut, maka disusun ekosistem mangrove dari masyarakat rencana strategi rehabilitasi ekosistem yang dipilih oleh instansi pemerintah, mangrove desa Nisombalia dengan partisipasi masyarakat dalam metode SWOT dan ditetapkan 8 pelestarian ekosistem mangrove, (delapan) strategi antara lain: 1) adanya peraturan perundang-undangan Mengembalikan fungsi mangrove yang berhubungan dengan pelestarian sesuai dengan pola ruang ekologi mangrove.

rehabilitasi; 2) pengadaan sarana

Unsur kelemahan (weakness) budidaya mangrove (pembibitan dan antara lain: Tingginya konversi penyemaian) yang dikelola langsung mangrove untuk pembukaan lahan oleh masyarakat; 3) peningkatan tambak, Rendahnya tingkat pendidikan kualitas SDM masyarakat sekitar masyarakat dan pemahaman tentang ekosistem mangrove; 4) Meningkatkan mangrove, Belum ada aturan dari tugas pokok kelompok masyarakat pemerintah setempat tentang larangan pengawas melalui bantuan operasional; penebangan mangrove. Unsur peluang 5) penegakan hukum dan penguatan (opportunity) antara lain: Adanya kelembagaan; 6) Penanaman kembali kesiapan pemerintah daerah dan kawasan pesisir mangrove yang Lembaga dalam pelaksanaan kegiatan terindentifikasi rusak berat karena rehabilitasi mangrove, Adanya program abrasi; 7) peningkatan partisipasi dan dukungan masyarakat, pemerintah masyarakat dan stakeholder lainnya 
dalam kegiatan rehabilitasi ekosistem mangrove; 8) pengembangan sistem tambak berbasis (silvofishery) yang baik.

Strategi-strategi tersebut diatas merupakan keputusan yang didesain untuk mencapai tujuan. Berdasarkan prioritas strategi analisis factor internal dan eksternal yang dihasilkan melalui analisis SWOT, maka secara sistematis ada 2 (dua) hal yang menjadi keputusan taktis untuk rekomendasi dalam upaya rehabilitasi ekosistem mangrove, yaitu; 1) Mengembalikan fungsi mangrove sesuai dengan pola ruang ekologi rehabilitasi; 2) pengadaan sarana budidaya mangrove (pembibitan dan penyemaian) yang dikelola langsung oleh masyarakat.

\section{KESIMPULAN}

Berdasarkan hasil penelitian yang telah dilakukan di Desa Nisombalia Kabupaten Maros, maka dapat disimpulkan sebagai berikut:

1. Pada stasiun di lokasi penelitian, stasiun I masuk dalam kriteria baik (sedang) dengan penutupan 50$75 \%$,stasiun II masuk dalam kategori baik (Sedang) dengan penutupan 50-75\%. Stasiun III masuk dalam kriteria rusak (jarang) dengan penutupan $<50 \%$.
2. Nilai Ekonomi Total di Desa Nisombalia Kecamatan Marusu pada saat penelitian adalah sebesar Rp 35.508.784.598,-

3. Ada 2 Arahan Strategi Rehabilitasi ekosistem mangrove di Desa Nisombalia yang menjadi prioritas utama yaitu: 1) Mengembalikan fungsi mangrove sesuai dengan pola ruang ekologi rehabilitasi; 2) pengadaan sarana budidaya mangrove (pembibitan dan penyemaian) yang dikelola langsung oleh masyarakat.

\section{SARAN}

1. Meningkatkan kontrol dan pengawasan di kawasan ekosistem mangrove agar kelestarian dan keanekaragaman jenis mangrove tetap terjaga.

2. Untuk penentuan luasan mangrove yang selanjutnya sebaiknya dilakukan dengan citra dengan resolusi spasial, spektral dan temporal yang lebih tinggi sehingga dalam proses intrepetasi menjadi lebih mudah dan digitasi dilakukan dalam resolusi yang baik tidak pecah-pecah.

\section{UCAPAN TERIMA KASIH}

Tulisan ini merupakan bagian dari penelitian tesis dan penulis 
mengucapkan terima kasih kepada Ketua Prodi Manajemen Pesisir dan Teknologi Kelautan dan Direktur Pasca Sarjana yang telah memberi kesempatan untuk melanjutkan pendidikan di PPS UMI.

\section{DAFTAR PUSTAKA}

Bengen, D.G. 2004. Menuju Pengelolaan Wilayah Pesisir Terpadu Berbasis Daerah Aliran Sungai (DAS), dalam Interaksi daratan dan Lautan : Pengaruhnya terhadap Sumber Daya dan Lingkungan, Prosiding Simposium Interaksi Daratan dan Lautan. Diedit oleh W.B. Setyawan, dkk. Jakarta : Kedeputian Ilmu Pengetahuan Kebumian, Lembaga Ilmu Pengetahuan Indonesia.

Dahuri, R. 2003. Keaneka Ragaman Hayati Laut: Aset Pembangunan Berkelanjutan Indonesia. Gramedia Pustaka Umum. Jakarta.

Fauzi, A.. 2006. Ekonomi Sumberdaya Alam dan Lingkungan. Jakarta : Gramedia Pustaka Utama

Ghufran, M. dan Kordi, K.M. 2012. Ekosistem Mangrove: potensi, fungsi, dan pengelolaan. Rineka Cipta. Jakarta.

Keputusan Menteri Negara Lingkungan Hidup Nomor : 201.2004. Kriteria Baku dan Pedoman Penentuan Kerusakan Mangrove. Deputi MENLH Bidang Kebijakan dan Kelembagaan Lingkungan Hidup : Jakarta.
Natividad, E.M.C., V.S. Hingabay, B. Harold, H.B. Lipae, A. Elani, E.A. Requieron, A.J. Abalunan, P.M. Tagaloguin, R.S. Flamiano, J.H. Jumawan, C. Joycelyn, and J.C. Jumawan. 2015. Vegetation analysis and community structure of mangroves in alabel and Maasim Sarangani Provinces, Philippines. ARPN J. of Agricultural and Biological Science, 10 (3):97-102

Noor, Y. R., M. Khazali dan I. N. N. Suryadipura. 1999. Panduan pengenalan mangrove di Indonesia. PKA/WI-IP, Bogor: 220 hall._.2006. Panduan Pengenalan Mangrove di Indonesia. Wetlands International. Bogor.

Notoatmodjo, S. 2002. Metodologi Penelitian Kesehatan. Rineka Cipta, Jakarta.

Setiyowati, S. 2016. Studi Perubahan Garis Pantai Pulau Untung Jawa Kepulauan Seribu Dki Jakarta. Skripsi. Fakultas Ilmu Tarbiyah Dan Keguruan. Universitas Islam Negeri (Uin) Syarif Hidayatullah. Jakarta.

Thomas M. L., dan Ralph W. K. 2000. Remote Sensing and Image Interpretation. John Willey \& Sons Inc. New York

Widhi, C., 2009. Kajian Ekologi Ekosistem Mangrove untuk Rehabilitasi di Desa Tiwoho Kecamatan Wori Kabupaten Minahasa Utara Provinsi Sulawesi Utara. IPB. Bogor. 